Int. J. Dev. Biol. 56: 543-550 (2012)

doi: $10.1387 / \mathrm{ijdb} .113477 \mathrm{tf}$

\title{
Peptide signaling in Hydra
}

\author{
TOSHITAKA FUJISAWA* and EISUKE HAYAKAWA* \\ Department of Developmental Genetics, National Institute of Genetics, Mishima, Japan
}

\begin{abstract}
Peptides play a number of crucial roles as signaling molecules in metazoans. In order to elaborate a more complete picture of the roles played by peptides in a single organism, we launched the "Hydra Peptide Project". For this project, we used Hydra magnipapillata, a species belonging to Cnidaria, one of the most basal metazoan phyla, and using a peptidomic approach, we systematically identified a number of peptide signaling molecules, their encoding genes and their functions. In this article, we report the peptides isolated from Hydra and other cnidarians, as well as their synthesis, processing and release from the cells to the target. Possible peptide signaling pathways are overviewed and finally we discuss the evolution of the peptide signaling system.
\end{abstract}

KEY WORDS: signaling peptides, Hydra, GPCR, signaling pathway, evolution

\section{Introduction to the Hydra peptide project}

Peptides play a number of crucial roles as signaling molecules in the cell activities of metazoans. For example, neuropeptides regulate a variety of physiological functions as neurotransmitters or hormones. Peptides of non-neuronal origin also mediate cellto-cell communication as hormones and maintain homeostasis of the organism. Cnidaria, one of the most basal metazoan phyla possesses the most primitive nervous system. It is believed that cnidarian ancestors acquired the first nervous system. In this context it is important to investigate neurotransmission in cnidarians. Grimmelikhuizjen and his coworkers (1992) have isolated a group of peptides related to molluscan FMRFamide (RFamide) from a variety of cnidarians and advocated that cnidarian neurotransmission is mediated exclusively by peptides. On the other hand, we launched a project in which peptide signaling molecules were systematically identified in Hydra, a cnidarian model organism with established infrastructures (Takahashi et al., 1997; see Fujisawa, 2008 for review). In this study peptides with less than 5 $\mathrm{kDa}$ in molecular weight were targeted. We identified a variety of peptides that are categorized into two groups. One group consists of neuropeptides and the other epitheliopeptides. In addition to neurotransmission, some neuropeptides trigger metamorphosis of planula larvae of a marine hydrozoan, Hydractinia echinata (Leitz et al., 1994; Leitz and Lay, 1994) and anthozoans, reef building corals (Iwao et al., 2004). As described later, a Hydra neuropeptide regulates neuron differentiation. Epitheliopeptides that are derived from epithelial cells most notably contribute to pattern formation and morphogenesis (Fujisawa, 2003). Antimicrobial peptides in Hydra are also produced from epithelial cells (Augustin and Bosch, 2010). In this article antimicrobial peptides and peptide toxins are not dealt with because they are somewhat out of scope of this review on signaling peptides.

In cell-to-cell communication, a peptide signal is commonly relayed via cell surface receptor. Receptors for peptide ligands are in most cases G-protein coupled 7 transmembrane receptors (GPCRs). Although GPCRs in cnidarians are poorly understood, a general scheme of signal transduction will be discussed. Peptide signaling is also discussed in the light of evolution.

\section{Peptides identified in cnidarians}

Grimmelikjuizen and his co-workers have isolated a number of neuropeptides from different kinds of cnidarians: from the anthozoans Anthopleura elegantisma and Renilla koellikeri; from the hydrozoans Polyorchis penicillatus and Hydra magnipapillata; from the scyphozoan Cyanea lamarckii (Table 1). Their neuropeptides include KAamide, Rlamides, RNamides, RWamides, RPamides and RFamides.

We had undertaken "Hydra peptide project" aiming at identifying all the signaling peptides in Hydra (see Fujisawa, 2008 for review). Neuropeptides we identified biochemically are also listed in Table 1. Most of the Hydra peptides are neurotransmitters and/ or neuromodulators. They may act directly on epithelial muscle

Abbreviations used in this paper: GPCR, G-protein coupled receptor.

\footnotetext{
*Address correspondence to: Toshitaka Fujisawa. Institute of Molecular Science, National Institutes of Natural Sciences, 5-1 Higashiyama, Myodaiji, Okazaki 444-8787, Japan. e-mail: tfujisaw@ims.ac.jp
} 
cells or indirectly via other neurons. The ectodermal epithelial cells have muscle processes running longitudinally, while endodermal epithelial cells contain circular muscle processes. Thus, in order to achieve body elongation endodermal muscles should contract and ectodermal muscles relax. To contract the body, ectodermal muscle processes contract while the endodermal ones relax. The availability of epithelial Hydra that is essentially made of epithelial cells (see in this issue the review by Shimizu, 2012) makes it easy to identify the target muscles of a neuropeptide. For example, if a peptide induces contraction of epithelial Hydra, it acts directly on the ectodermal muscle processes. If a peptide has no effect on epithelial Hydra but induces contraction of normal Hydra, the peptide very likely acts on other neurons to induce secretion of some peptide that in turn causes ectodermal muscle contraction. Among neuropeptides, Hym-355 is unique in that it has no effect on muscle contraction but is rather positively involved in neuron differentiation (Takahashi et al., 2000; see below). In addition to the peptides listed in Table 1, several novel neuropeptides by using HPLC-tandem Mass-spectrometry (LC-MS/MS) have been identified (Takahashi et al, unpublished).

Peptides derived from epithelial cells are referred to as epitheliopeptides and they are primarily involved in pattern formation or morphogenesis in Hydra. Their list has been published elsewhere (Fujisawa, 2003, 2008). Some of the epitheliopeptides (Hym323, Pedin/Hym-330 and Pedibin/Hym-346) are involved in foot formation (Hoffmeister, 1996; Grens et al., 1999; Harafuji et al.,

TABLE 1

\section{BIOCHEMICALLY IDENTIFIED CNIDARIAN NEUROPEPTIDES}

\begin{tabular}{|c|c|c|c|c|}
\hline Species & Peptide & Structure & Function & Refs \\
\hline Anthopleura elegantissima & KAamide & L-3-phenyllactyl FKAa & Inhibition of muscle contraction & a), b) \\
\hline \multirow[t]{12}{*}{ (Anthozoa) } & Rlamide I & L-3-phenyllactyl YRla & Inhibition of muscle contraction & $\mathrm{b}, \mathrm{c})$ \\
\hline & II & YRla & & c) \\
\hline & RNamide I & L-3-phenyllactyl LRNa & Induction/inhibition of muscle contraction & $\mathrm{d}, \mathrm{e})$ \\
\hline & II & LRNa & & f) \\
\hline & RWamide I & $<$ QSLRWa & Muscle contraction & $g, h)$ \\
\hline & II & $<Q G L R W a$ & Muscle contraction & $h, i)$ \\
\hline & RPamide I & LPPGPLPRPa & & j) \\
\hline & II & $<$ QNFHLRPa & & k) \\
\hline & III & & & f) \\
\hline & IV & & & f) \\
\hline & $\mathrm{V}$ & & & f) \\
\hline & RFamide family & & Induction/inhibition of muscle contraction & $\mathrm{I}, \mathrm{m})$ \\
\hline Renilla koellikeri (Anthozoa) & RFamide & $<Q G R F a$ & & n) \\
\hline Cyanea lamarckii & RFamide I & $<$ QWLRGRFa & & o) \\
\hline \multirow[t]{2}{*}{ (Scyhozoa) } & II & $<$ QPLWSGRFa & & o) \\
\hline & III & GRFa & & o) \\
\hline Polyorchis penicilltus & RFamide I & $<$ QLLGGRFa & & p) \\
\hline (Hydrozoa) & II & $<$ QWLKGRFa & & q) \\
\hline Hydra magnipapillata & RFamide I & $<$ QWLGGRFa & & r) \\
\hline \multirow[t]{3}{*}{ (Hydrozoa) } & II & $<$ QWFNGRFa & & r) \\
\hline & RFamide III/IV & (KP)HLRGRFa & Enhance body pumping & r) \\
\hline & GLWamide family & & Induction of metamorphisis of planula larvae & $\mathrm{s}, \mathrm{t}, \mathrm{u})$ \\
\hline Anthopleura elegantissim & Metamorphosisn A & $<Q Q P G L W a$ & & s) \\
\hline \multirow[t]{16}{*}{ Hydra magnipapillata } & Hym-53 & NPYPGLWa & Enhance bud detachmen $\mathrm{t}$ & t) \\
\hline & Hym-54 & GPMTGLWa & Enhance bud detachmen $t$ & t) \\
\hline & Hym-248 & EPLPIGLWa & $\begin{array}{l}\text { Enhance bud detachment; } \\
\text { Body elongation }\end{array}$ & t) \\
\hline & Hym-249 & KPIPGLWa & Enhance bud detachmen $\mathrm{t}$ & t) \\
\hline & Hym-331 & GPPPGLWa & Enhance bud detachmen $t$ & t) \\
\hline & Hym-338 & GPP $^{\mathrm{h}} \mathrm{PGLWa}{ }^{11}$ & Enhance bud detachmen $t$ & t) \\
\hline & Hym-370 & KPNAYKGKLPIGLWa & Enhance bud detachmen $t$ & u) \\
\hline & Hym-1071 & KPPWRGGM(O)W & & v) \\
\hline & Hym-176 & APFIFPGPKVa & Contraction of peduncle & w) \\
\hline & Hym-357 & KPAFLFKGYKPa & Contraction of whole body & w) \\
\hline & Hym-690 & KPLYLFKGYKPa & Contraction of whole body & v) \\
\hline & Hym-355 family & & & \\
\hline & Hym-355 & FPQSFLPRGa & Enhance neuron differentiation & $\mathrm{x})$ \\
\hline & FRamide family & & & \\
\hline & Hym-65 (FRamide 1) & IPTGTLIFRa & Body elongation & y) \\
\hline & Hym-153 (FRamide-2) & APGSLLFRa & Body contraction & y) \\
\hline
\end{tabular}

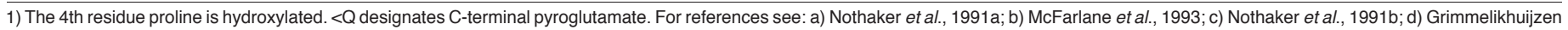

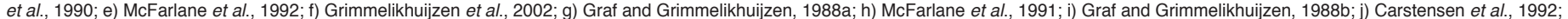

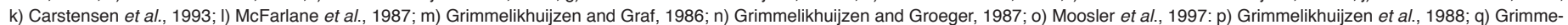

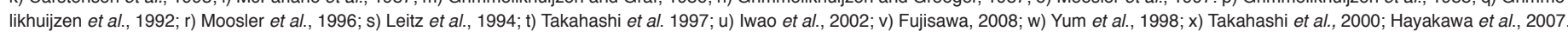




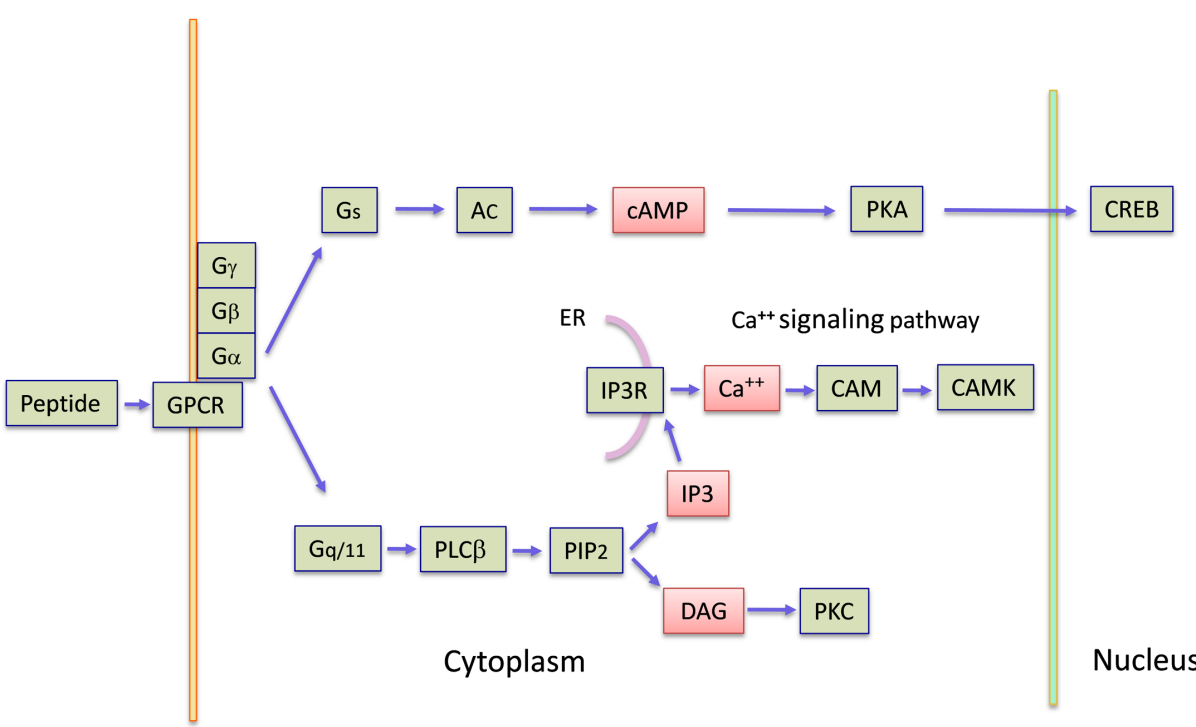

Fig. 1. Peptide - Gprotein coupled receptor (GPCR) signaling pathways. peptide at its $\mathrm{N}$-terminus. The protein is targeted to the endoplasmic reticulum (ER) and the signal peptide is cleaved off to enter the Golgi network. Modification like glycosylation or sulfation at a certain amino acid residue occurs during traversing the Golgi network. Peptides are then packed in secretory vesicles where processing of the protein into peptides and modification at the $\mathrm{N}$-terminus (e.g. acetylation or pyro-glutamate formation) or at the $\mathrm{C}$-terminus (amidation) takes place. Cnidarian neuropeptides have been localized by immunogold-electronmicroscopy. For example, Hydra RFamides are localized in the dense-core vesicles of peduncle neurons (Koizumi et al. 1989). Antho-RFamides and Antho-RWamides are also localized in excretory vesicles in neurons of anthozoans (Westfall and Grimmelikhuijzen, 1993; Westfall et al., 1995).

These vesicles are directed mainly to the 2001). These peptides contain no modified residues. An amidated peptide with a single intramolecular disulfide bridge, Hym-301 is involved in tentacle formation (Takahashi et al., 2005). As has been pointed out, it is in good agreement with the notion that epithelial cells in Hydra are a primary cell type to regulate pattern formation/ morphogenesis in Hydra (Fujisawa, 2008). Epitheliopeptides with PW residues at the $\mathrm{C}$-terminus inhibit neuron differentiation and counteract against the action of Hym-355 (Takahashi et al., 1997; 2000 , 2009). The PW peptides presumably monitor the density of neurons (neurons/epithelial cells) in the body column. If the density of neuron is low, PW peptides do not exert their effect so that the action of Hym-355 could prevail. When the neuron density becomes higher, PW peptides are presumably released extracellularly to counteract against the positive feedback of neuron differentiation by Hym-355. In this way homeostasis of a neuron population is maintained in the Hydra body.

There are two remarkable Hydra peptides reported to be a neuropeptide (head activator) (Schaller and Bodenmueller, 1981) and an epitheliopeptide (HEADY) (Lohmann and Bosch, 2000). Unfortunately, however, genes encoding these peptides are not found in the Hydra genome database (see in this issue Steele, 2012). Thus, the existence of these peptides remains elusive.

\section{Synthesis and release of signaling peptides}

Signaling peptides are encoded in a larger precursor protein, which is post-translationally processed via cleavage by specific proteolytic enzymes called prohormone convertases to produce functional units. Processing and cleavage patterns and signal transduction pathways vary dependent on peptide species and cell types. A famous example is proopiomelanocortin, which differentially produces at least 10 different peptide hormones that distribute in the anterior and intermediate lobes of the pituitary gland, hypothalamus and skin (Pritchard and White, 2007).

\section{Neuropeptides: RFamides, RWamides}

Most of neuropeptides so far identified in cnidarians are short (around 10 amino acid-long). The precursor protein contains a signal presynaptic membrane where contents of the vesicles are released upon stimulation to the synaptic cleft. The released peptide binds to its receptor on the postsynaptic cells so that the signal could be transmitted to the target cells. However, Antho-RFamides are also detected in non-synaptic vesicles (Westfall and Grimmelikhuijzen, 1993). In the planula larva of the hydrozoan Pennaria tiarella the peptide packed-vesicles are found all along the neurite in close contact with the cell membrane (Brumwell and Martin, 1996). Since RFamides inhibit the action of GLWamides that induces metamorphosis of the planula larva of the hydrozoan Hydractinia echinata (Katsukura et al., 2003), release of these peptides may occur in the non-synaptic regions as a paracrine factor.

\section{Epitheliopeptides \\ Precursors with a signal peptide}

Hym-301 is so far the only epitheliopeptide with the C-terminal amidation in cnidarians. Since its precursor has a similar structure to the neuropeptide precursors, the peptides are expected to localize in secretory vesicles. Immuno-electronmicroscopy using an anti-Hym-301 antibody revealed that the peptide localize in secretory vesicles called electron-dense inclusions (West, 1978; Wood, 1979) that are located at the apical part of the ectodermal epithelial cells in the head region (Fig. 3; Takaku et al., unpublished results). These vesicles are almost 10 times larger in size (1 1.5 $\mu \mathrm{m}$ in a long axis) comparing to dense-cored vesicles in neurons. The Hym-301 peptide appears to be released outside of cells and also into the cytoplasm.

The precursor of PW peptides is also predicted to have a signal peptide and cleaved at dibasic amino acids at least at the C-terminus of each peptide (Takahashi et al., 2009). However, its subcellular localization is still unknown.

\section{Precursors lacking a signal peptide}

Hym-323, Pedin/Hym-330 and Pedibin/Hym346 are involved in foot formation (see Fujisawa, 2008 for review) and all of their precursors lack a signal peptide. Nevertheless, Pedibin/Hym-346 is found secreted extracellularly when tested with the yeast invertase secretion assay (Böttger et al., 2006). Although the mechanism 
of its secretion is unknown, some of the proteins without a signal peptide are secreted extracellularly via a chaperon-like protein (Piotrowicz et al., 1997; Suzuki et al., 2010). Also, a large number of peptides secreted independent of the classical ER-Golgi vesicular pathway have been reported in a large scale peptidomic analysis of mouse brain (Fricker, 2010).

\section{Signal transduction}

\section{G-protein coupled receptor (GPCR) signaling}

G Protein-coupled receptors (GPCRs) have seven transmembrane domains; the $\mathrm{N}$-terminal region is extracellular, three loops extend each outside and inside the membrane and the C-terminal region is cytoplasmic. There are seven GPCR families that are classified by their structures and functions. The family 1 is rhodopsinlike and the largest group whose ligands are biogenic amines, peptides, glycoprotein hormones, odorants, purines, eicosanoids etc. Signaling peptides generally bind to family 1 GPCRs. Family 2 is secretin-like whose ligands are mostly polypeptide hormones like glucagon, pituitary adenylate cyclase-activating polypeptide (PACAP), vasoactive intestinal polypeptide (VIP) etc. Family 3 includes metabotropic glutamate receptors. Other four families form minor groups. We found 663 family 1 GPCR genes in the Hydra genome (Hayakawa and Fujisawa, unpublished). Majority of these GPCR genes appear to be intact. Among the GPCRs, 63 are opsins in Hydra (Suga et al., 2008).

In Hydra there is no known GPCR whose ligand is a peptide, although several GPCRs show significant structural similarities to neuropeptide GPCRs in higher organisms. General scheme for signal transduction of Family 1 GPCR is shown in Fig. 1 (taken from GnRH signaling in KEGG pathway maps, KEGG (http://www. genome.jp/kegg/) and modified). Heterotrimeric $\mathrm{G}$ proteins ( $\alpha, \beta$, $\gamma$ subunits are coupled with a GPCR. Once a ligand binds to the receptor, GTP replaces GDP that binds to $G$ protein $\alpha$ subunit $G \alpha$ and the $G \alpha$ is dissociated from $\beta \gamma$ dimmer $(G \beta \gamma)$ to activate enzymes in the signal transduction cascade. There are four subtypes of $\mathrm{G} \alpha$ (Gs, Gq/11, Gi/o and G12/13 ) classified by their amino acid sequences. Fig. 1 shows three representative pathways that are activated by $\mathrm{Gs}$ and $\mathrm{Gq} / 11$. Gs activates adenylate cyclase $(A C)$ that produces cAMP as a second messenger, which in turn activates protein kinase $A$ (PKA). PKA is involved in numerous reactions including activation of a transcription factor CREB. Gq/11 activates phospholipase C $\beta$ (PLC $\beta$ ) which hydrolyses the membrane phospholipid, phosphatidylinositol (4,5)-bisphosphate (PIP2) into two second messengers inositol 1,4,5-triphosphate (IP3) and diacylglycerol (DAG). IP3 binds to IP3 receptor on the $\mathrm{ER}$ inducing $\mathrm{Ca}^{++}$release. Released $\mathrm{Ca}^{++}$may bind to many $\mathrm{Ca}^{++}$ binding proteins that mediate variety of biological effects of $\mathrm{Ca}^{++}$. One of them, calmodulin ( $\mathrm{CaM})$ activates calcium-calmodulindependent protein kinases (CaMKs) that also exert various effects. On the other hand DAG activates protein kinase $C$ (PKC), which activates many cytosolic proteins. The genes encoding all of the proteins described here have their homologues in Hydra genome (Chapman et al. 2010).

\section{Insulin signaling}

The insulin signaling pathway has been characterized in detail in bilateral animals and is responsible for regulations of metabolism, longevity and growth (Taguchi and White, 2008). In Hydra, one of the receptor tyrosine kinase genes, HTK7 encodes a member of insulin receptor family (Steele et al., 1996). HTK7 is suggested to regulate growth and patterning. However, its ligand is not known. The search in the Hydra ESTs has yielded three genes encoding insulin-like peptides (Nishimiya-Fujisawa and Fujisawa, unpublished; Steele unpublished). One of them is roughly the same size as mammalian insulins, while other two are larger with extended $\mathrm{N}$-terminal regions. Two of the genes can rescue the growth defects in Drosophila, in which cells producing insulin-like peptides were ablated (Steele, personal communication). Thus, the functions of the peptides are conserved from Cnidaria to Arthropoda, although in vivo functions in Hydra remain to be discovered. The insulin signaling pathway obtained from higher metazoans is shown in Fig. 2 (taken from insulin signaling in KEGG pathway maps, KEGG (http://www.genome.jp/kegg/) and modified).

Insulin binds to an insulin receptor which is composed of two $\alpha$ subunits and two $\beta$ subunits. The insulin receptor phosphorylates insulin receptor substrates (IRSs). In the phosphatidylinositol signaling pathway, the IRS binds to PI3K, which phosphorylates phosphatidylinositol (4,5)-bisphosphate (PIP2) to produce a second messenger, phosphatidylinositol (3,4,5)-trisphosphate (PIP3). PIP3 is negatively regulated by phosphatase and tensin homolog (PTEN). PIP3 activates 3-phosphoinositidedependent kinase, PDK1/2 that in turn phosphorylates serine/ threonine kinase, Akt. Activated Akt phosphorylates, thus inhibits a fork-head transcription factor, FOXO by promoting its nuclear export and glycogen synthase kinase (GSK)

(n)

Fig. 2. Insulin signaling pathways.

\section{Cytoplasm}

Nucleus
Proliferation Differentiation
Metabolism Stress response Apoptosis

$$
\text { Glycogenesis }
$$

(n)

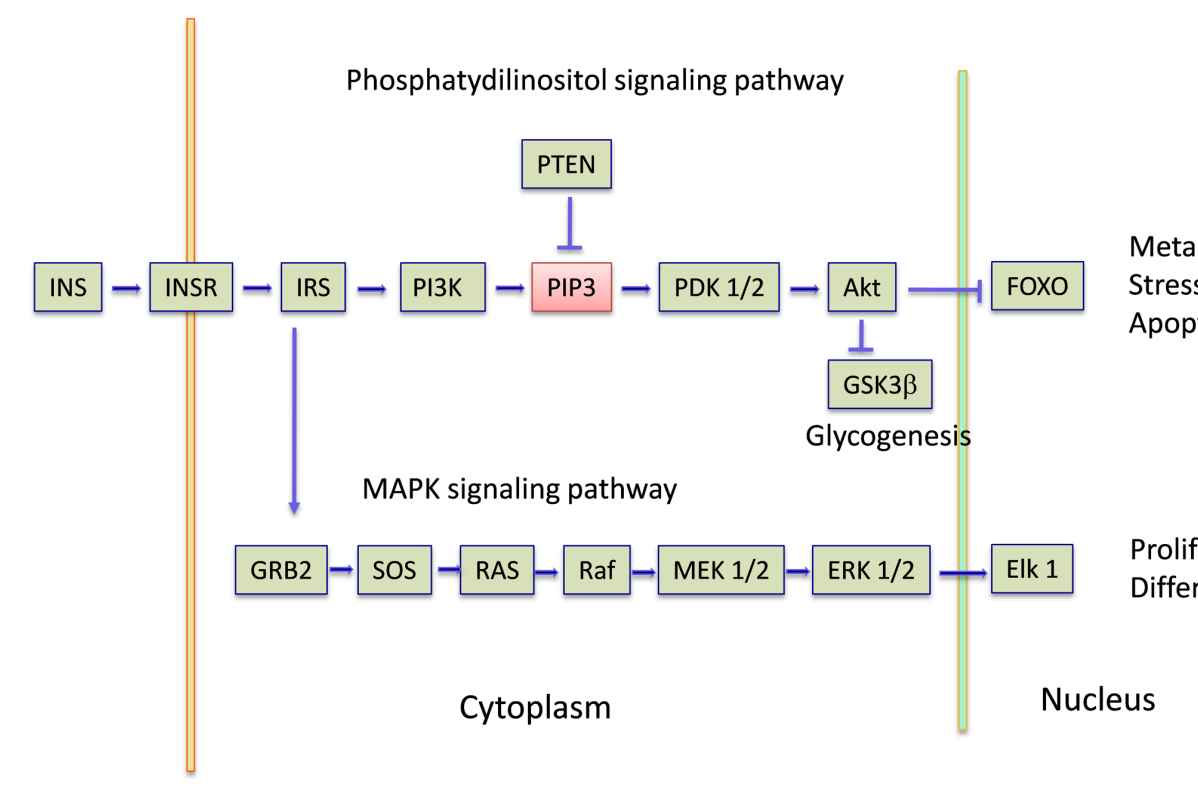




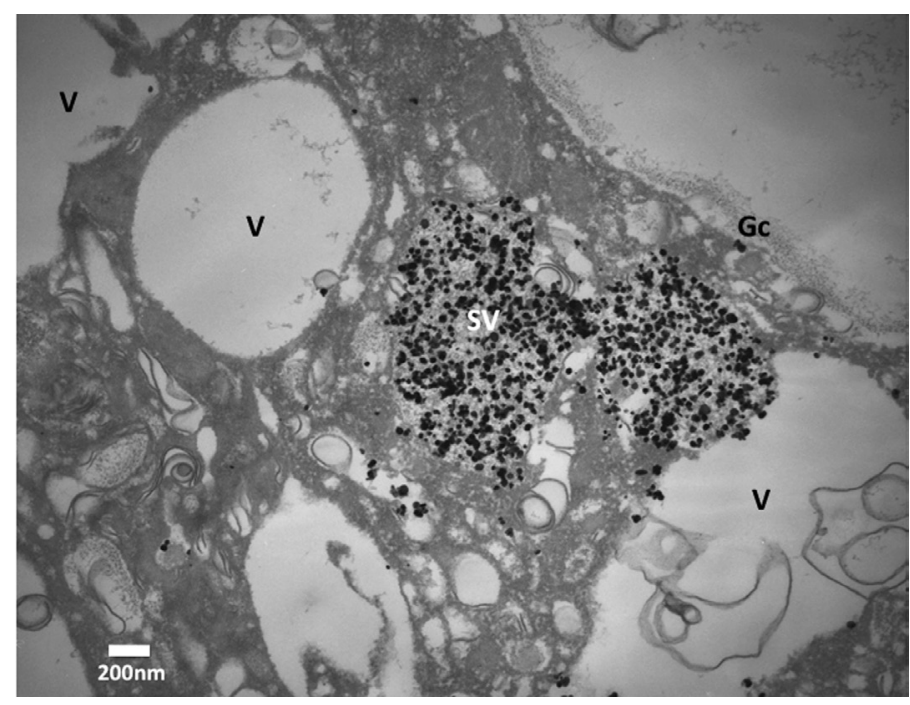

Fig. 3. Immuno-electron microscopy using an anti-Hym-301 antibody. Notice the numerous gold particles in the secretory vesicles (SV) located in the ectodermal epithelial cell. Gc, glycocalyx; V, vacuole.

$3 \beta$. In the MAPK signaling pathway, IRS associates with growth factor receptor-bound protein, GRB-2. The complex activates Son of Sevenless (SOS) by removing GDP from and adding GTP to Ras, which then pushes the MAPK cascade down with sequential phosphorylation. Elk1 is a transcription factor that activates genes involved in cell proliferation and differentiation. The MAPK cascade and CREB signaling in regeneration have been reported in Hydra (Galliot et al., 1995; Kaloulis et al., 2004; Chera et al., 2007; Chera et al., 2011). All of the genes encoding the proteins described here except for Elk1 have their homologues in Hydra genome (Galliot et al., 1995; Fujisawa, unpublished). ERK 1/2 might activate other transcription factors like c-myc or other ETS domain containing transcription factors.

\section{Evolutionary considerations concerning peptides, receptors and channels}

\section{Peptides}

Peptides described in this review are rather short and the motif essential for the function is even shorter (two or three amino acid-long). Thus, it is generally difficult to discuss the evolutionary conservation of peptides. Only short peptides conserved among cnidarians are RFamide and GLWamide families. When many peptides with the same motif are encoded in a precursor protein, it is relatively easy to find homologs based on the conserved motif among other animals even in different phyla. RFamides are such an example. RFamides appear to be conserved from cnidarians to mammals and some of the functions like cardiac muscle contraction (or pumping) can be seen from Hydra to man (Shimizu and Fujisawa, 2003).

GLWamides are easily found among cnidarians with the same approach as for RFamides. But, when it comes to other phyla, it becomes difficult to find homologs by conventional searches such as BLAST. Instead one has to search by considering the conserved structural hallmarks, e.g. presence of a signal peptide, dibasic cleavage sites, amidation motifs and conserved motifs in mature peptide sequences. By doing so, we identified a GLWamide precursor protein in $C$. elegans (Ishihara et al., unpublished data, 1998; Fujisawa, 2008) and later this was confirmed biochemically (Husson etal., 2005). Homologs of GLWamide genes have not been detected in other metazoans. Thus, it is apparent that RFamides and GLWamides were acquired in the first nervous system of cnidarian ancestors and not only the amino acid motifs but also their basic functions appear to be maintained in extant metazoans.

It is conceivable that orthologs of other peptide families may be found in animals in different phyla. However other peptide genes such as Hym-176 and Hym-301 or their related genes are not found outside of Hydra. These paralogs, although related, have rather diverse sequences. Thus, an ancestral gene was presumably acquired after Hydra branched from other hydrozoans and later diverged to perform related but different functions. These genes are referred to as taxonomically restricted genes that play a role in the creation of phylum (or even family)-specific novelties (Milde et al., 2009).

\section{G-protein coupled receptors}

As mentioned above the signaling pathway of GPCR appears to be well conserved from Hydra to mammals indicating that the whole pathway is important for animal survival. The number of GPCRs per genome generally increases as the phylogenetic order goes up and this increase is mainly attributed to the expansion of odorant or chemosensory receptors (Table 2). A unicellular eukaryote, Tetrahymena has only several GPCRs (Lampert et al., 2011) while slime mold, Dictyostelium discoideum has 55 genes for GPCR (Prabhu et al., 2007). One of the most primitive metazoan, sponge has more than 200 GPCRs. The sudden increase in the number of GPCRs appears to occur to attain multicellularity of animals. $C$. elegans has 1006 odorant/chemosensory receptors among 1149 GPCRs (Table 2; see Frederiksson et al., 2005).

Unexpectedly Hydragenome contains 822 GPCRs, 663 related to family-1, 41 to family-2 and 118 to family-3 (Hayakawa and Fujisawa, unpublished observation), Nematostella about 500. As in case of vertebrates but not of $C$. elegans and Drosophila, most of the Hydra GPCR genes are single exon genes. They are arrayed in tandem along the contigs. Also, most of them appear to

\section{TABLE 2}

NUMBER OF GPCR GENES IN REPRESENTATIVE EUKARYOTE GENOMES

\begin{tabular}{lcl} 
Organism(s) & Number & References \\
\hline Yeasts & $3-9$ & Frederiksson and Schio, 2005 ${ }^{1)}$ \\
Plants & $1-6$ & Frederiksson and Schio, 2005 ${ }^{1)}$ \\
Slime mold (Dictyostelium) & 55 & Prabhu et al., 2007 \\
Tetrahymena & Several & Lampert et al., 2011 \\
Sponge (Amphimedon) & $>200$ & Srivastava, et al., 2010 \\
Hydra magnipapillata & 822 & Hayakawa et al., unpublished \\
Sea anemone (Nematostella) & $\sim 500$ & Hayakawa et al., unpublished \\
Nematode (C. elegans) & 1149 & Frederiksson and Schio, 2005 ${ }^{1)}$ \\
$\quad$ Odorant receptors & $1006 / 1149$ & Frederiksson and Schio, 2005 \\
Fruit fly (D. melanogaster) & 210 & Frederiksson and Schio, 2005 ${ }^{1)}$ \\
Tunicate (Ciona) & 208 & Frederiksson and Schio, 2005 ${ }^{1)}$ \\
Zebrafish (Danio) & 1318 & Frederiksson and Schio, 2005 ${ }^{1)}$ \\
Mouse (Mus) & 737 & Frederiksson and Schio, 2005 ${ }^{1)}$ \\
Human (Homo) & 865 & Frederiksson and Schio, 2005 ${ }^{1)}$ \\
\hline
\end{tabular}

1) Review article 
be intact. The reason for this abundance of GPCRs in cnidarians is not known. One explanation might be that at least Hydra uses a few hundreds of peptides as signaling molecules and thus the receptors for these ligands are numerous. The other possibility is that cnidarians uses many chemosensory receptors to monitor environmental cues although there are no good reasons that cnidarians should have so many chemosensory receptors. In any case, the genes with a single exon suggest that the burst of GPCR gene expansion presumably occurred recently in the lineage of Hydra evolution since Hydra diverged from anthozoans at least 500 millions year ago (Chapman et al., 2010).

\section{RFamide-gated ion channels (FaNaCs)}

As mentioned above, receptors for peptides are in most cases GPCRs. To date, only exception to this rule is the FMRFamidegated $\mathrm{Na}^{+}$channel first identified in snail Helix asperosa (Cotrell et al., 1990; Lingueglia et al, 1995). FaNaC is a member of the degenerin/epithelial $\mathrm{Na}^{+}$channel (DEG/ENaC) family that also includes acid-sensing ion channels (ASICs) (Lingueglia, 2007) (see also in this issue the review on ligand-gated ion channels by Pierobon). The channels in this family are activated by ligands (ASICs) and mechanical forces (degenerins) or opened constitutively (ENaCs) but are blocked by a diuretic drug amiloride. The channel has two transmembrane domains with a long extracellular loop with a cysteine-rich region and $\mathrm{N}$-terminal and $\mathrm{C}$-terminal cytoplasmic domains (Kellenberger and Schild, 2002). Hydra contains 4 subunits for FaNaCs designated to as $\mathrm{HyNaC}$ 2, 3, 4 and 5 . HyNaC2, 3 and 5 form an ion channel gated by Hydra RFamide I and II (Golubovic et al., 2007; Dürrnagel et al., 2010). HyNaC 4 might form the channel with yet un-identified subunits.

Whole mount in situ hybridization shows that the genes encoding these subunits are all expressed in most likely epitheliomuscular cells at the base of the tentacles with a subtle but interesting difference (Dürrnagel et al., 2010). The precise in vivo function of this channel in Hydra is unknown. However, since the regions expressing these genes and the gene encoding RFamides I and II roughly coincide, the channel may mediate fast axonal transmission to muscle cells at the base of the tentacles to regulate tentacle movement. Recent finding also suggest its involvement in feeding response because amiloride delayed feeding response evoked by glutathione (Dürrnagel et al., 2010). This type of channel has been found only in Cnidaria and Mollusca and therefore its evolutionary pathway is unclear. The absence of the channel in other phyla may be a gene loss or due to a technical problem to detect it. Independent incidence to acquire the channels in different phyla is highly unlikely because the same type of neuropeptide gates the channels.

\section{Acknowledgement}

Most of the work described here was done at the National Institute of Genetics (Mishima, Japan) supported by grants from Ministry of Education, Culture, Sports, Science and Technology, Japan (to T.F.). T.F. also thanks the Deutsche Forschungsgemeinschaft and Thomas Holstein, University of Heidelberg for support and hospitality.

\section{References}

AUGUSTIN, R. and BOSCH, T.C.G. (2010). Cnidarian immunity: a tale of two barriers. Adv Exp Med Biol. 708:1-16.

BÖttger, A., StRasser, D., ALEXANDROVA, O., LeVIN, A., FISCHER, S.,
LASI, M., RUDD, S. and DAVID, C.N. (2006). Genetic screen for signal peptides in Hydra reveals novel secreted proteins and evidence for non-classical protein secretion. Eur J Cell Biol 85: 1107-1117.

BRUMWELL, G.B. and MARTIN, V.J. (1996). Ultrastructural localization of RFamidelike peptides in neuronal dense-cored vesicles of a cnidarian planula larva. Invertebr Biol 115: 13-19.

CARSTENSEN, K., RINEHART, K.L., MCFARLANE, I.D. and GRIMMELIKHUIJZEN, C.J.P. (1992). Isolation of Leu-Pro-Pro-Gly-Pro-Leu-Pro-Arg-Pro-NH2 (Antho$\mathrm{RPamide}$ ), an $\mathrm{N}$-terminally protected, biologically active neuropeptide from sea anemones. Peptides (Tarryt.), 13: 851-857.

CARSTENSEN, K., MCFARLANE, I.D, RINEHARD, K.L, HUDMAN, D., SUN, F. and GRIMMELIKHUIJZEN, C.J.P. (1993). Isolation of <Glu-Asn-Phe-His-Leu-ArgPro-NH2 (Antho-RPamide II), a novel, biologically active neuropeptide from sea anemones. Peptides (Tarryt.) 14: 131-135.

CHAPMAN, J.A., KIRKNESS, E.F., SIMAKOV, O., HAMPSON, S.E., MITROS, T., WEINMAIER, T. RATTEI, T., BALASUBRAMANIAN, P.G., BORMAN, J., BUSAM, D. et al. (2010). The dynamic genome of Hydra. Nature 464: 592-596.

CHERA, S., KALOULIS, K. and GALLIOT, B. (2007). The cAMP response element binding protein (CREB) as an integrative HUB selector in metazoans: clues from the hydra model system. Bio Systems 87:191-203.

CHERA, S., GHILA, L., WENGER, Y. and GALLIOT, B. (2011). Injury-induced activation of the MAPK/CREB pathway triggers apoptosis-induced compensatory proliferation in hydra head regeneration. Dev Growth Differ 53:186-201.

COTTRELL, G.A., GREEN, K.A. and DAVIES, N.W. (1990). The neuropeptide PheMet-Arg-Phe-NH2 (FMRFamide) can activate a ligand-gated ion channel in Helix neurones. Pflugers Arch 416: 612-614.

DÜRRNAGEL, S., KUHN, A., TSIAIRIS, C.D., WILLIAMSON, M., KALBACHER, H. GRIMMELIKHUIJZEN, C.J.P., HOLSTEIN, T.W. and GRÜNDER, S. (2010). Three homologous subunits form a high affinity peptide-gated ion channel in Hydra. $J$ Biol Chem 285: 11958-11965.

FREDRIKSSON, R. and SCHOETH, H.B. (2005). The repertoire of G-protein-coupled receptors in fully sequenced genomes. Mol Pharmacol 67: 1414-1425.

FRICKER, L.D. (2010). Analysis of mouse brain peptides using mass spectrometrybased peptidomics: Implications for novel functions ranging from non-classical neuropeptides to microproteins. Mol Biosyst 6: 1355-1365.

FUJISAWA, T. (2003). Hydraregeneration and epitheliopeptides. Dev Dyn226: 182-189.

FUJISAWA, T. (2008). Hydra peptide project 1993-2007. Dev Growth Differ 50 Supp 1: 257-268.

GALLIOT,B., WELSCHOF, M., SCHUCKERT, O., HOFFMEISTER, S. and SCHALLER, $H$. (1995). The CAMP response element binding protein is involved in hydra regeneration. Development 121: 1205-1216.

GOLUBOVIC, A., KUHN, A., WILliamSON, M., KALBACHER, H., HOLSTEIN, T.W., GRIMMELIKHUIJZEN, C.J.P. and GRÜNDER, S.(2007). A peptide-gated ion channel from the freshwater polyp Hydra. J Biol Chem 282: 35098-35103.

GRAFF, D. and GRIMMELIKHUIJZEN, C.J.P. (1988a). Isolation of <Glu-Ser- LeuArg-Trp-NH2, a novel neuropeptide from sea anemones. Brain Res 442: 354-358.

GRAFF, D. and GRIMMELIKHUIJZEN, C.J.P. (1988b). Isolation of <Glu-Gly-LeuArg-Trp-NH2 (Antho-RWamide II), a novel neuropeptide from sea anemones. FEBS Lett 239: 137-140.

GRENS, A., SHIMIZU, H., HOFFMEISTER, S., BODE, H.R. and FUJISAWA, T. (1999). Pedibin/Hym-346 lowers positional value thereby enhancing foot formation in Hydra. Development 126: 517-524.

GRIMMELIKHUIJZEN, C.J.P. and GRAFF, D. (1986). Isolation of <Glu-Gly-Arg-Phe$\mathrm{NH} 2$ (Antho-RFamide), a neuropeptide from sea anemones. Proc Natl Acad Sci USA 83: 9817-9821.

GRIMMELIKHUIJZEN, C.J.P. and GROEGER, A. (1987). Isolation of the neuropeptide pGlu-Gly-Arg-Phe-amide from the pennatulid Renilla köllikeri. FEBS Lett 211: 105-108.

GRIMMELIKHUIJZEN, C.J.P., HAHN, M., RINEHART, K.L. and SPENCER, A.N (1988). Isolation of <Glu-Leu-Leu-Gly-Gly-Arg-Phe-NH2 (Pol-RFamide), a novel neuropeptide from hydromedusae. Brain Res 475: 198-203.

GRIMMELIKHUIJZEN, C.J.P., RINEHART, K.L., JACOB, E., GRAFF, D., REINSCHEID, R.K., NOTHACKER, H.-P. and STALEY, A.L. (1990). Isolation of L-3-phenyllactylLeu-Arg-Asn-NH2 (Antho-RNamide), a sea anemone neuropeptide containing an unusual amino-terminal blocking group. Proc Natl Acad Sci USA 87: 5410-5414. 
GRIMMELIKHUIJZEN, C.J.P., DARMER, D., SCHMUZLER, C., CARSTENSEN, K., MOOSLER, A., NOTHACKER, H. P. REINSCHEID, R.K., VOLLERT, H., RINEHART, K.K. and MCFARLANE, I.D. (1992). The peptidergic nervous system of coelenterates. Prog Brain Res 92: 137-148.

GRIMMELIKHUIJZEN, C.J.P., WILLIAMSON, M. and HANSEN, G.N. (2002). Neuropeptides in cnidarians. Can J Zool 80: 1690-1702.

HARAFUJI, N., TAKAHASHI, T., HATTA, M., TEZUKA, H., MORISHITA, F., MATSUSHIMA, O. and FUJISAWA, T. (2001). Enhancement of foot formation in Hydra by a novel epitheliopeptide, Hym-323. Development 128: 437-446.

HAYAKAWA, E., TAKAHASHI, T., NISHIMIYA-FUJISAWA, C. and FUJISAWA, T. (2007). A novel neuropeptide (FRamide) family identified by a peptidomic approach in Hydra magnipapillata. FEBS J 274: 5438-5448.

HUSSON, S.J., CLYNEN, E., BAGGERMAN, G., DE LOOF, A. and SCHOOFS, L. (2005). Discovering neuropeptides in Caenorhabditis elegans by two dimensional liquid chromatography and mass spectrometry. Biochem Biophys Res Comm 335: 76-86.

HOFFMEISTER, S.A.H. (1996). Isolation and characterization of two new morphogenetically active peptides from Hydra vulgaris. Development 122: 1941-1948.

IWAO, K., FUJISAWA, T. and HATTA, M. (2002). A cnidarian neuropeptide of the GLWamide family induces metamorphosis of reef-building corals in the genus Acropora. Coral Reefs 21: 127-129.

KALOULIS, K., CHERA, S., HASSEL, M., GAUCHAT, D. and GALLIOT, B. (2004). Reactivation of developmental programs: the cAMP-response element-binding protein pathway is involved in hydra head regeneration. Proc Natl Acad Sci USA 101: 2363-2368.

KATSUKURA, Y., DAVID, C.N., GRIMMELIKHUIJZEN, C.J. and SUGIYAMA T. (2003). Inhibition of metamorphosis by RFamide neuropeptides in planula larvae of Hydractinia echinata. Dev Genes Evol 213: 579-586.

KELLENBERGER, S. and SCHILD, L. (2002). Epithelial sodium channel/degenerin family of ion channels: a variety of functions for a shared structure. Physiol Rev 82: 735-767

KOIZUMI, O., WILSON, J.D., GRIMMELIKHUIJZEN, C.J. and WESTFALL, J.A. (1989). Ultrastructural localization of RFamide-like peptides in neuronal densecored vesicles in the peduncle of Hydra. J Exp Zool 249: 17-22.

LAMPERT, T.J., COLEMAN, K.D. and HENNESSEY, T.M. (2011). Chemoattraction to lysophosphatidic acid does not require a change in membrane potential in Tetrahymena thermophila. Cell Biol Int 35: 519-528.

LEITZ, T., MORAND, K. and MANN, M. (1994). Metamorphosin A: a novel peptide controlling development of the lower metazoan Hydractinia echinata (Coelenterata, Hydrozoa). Dev Biol 163: 440-446.

LEITZ, T. and LAY, M. (1994). Metamorphosin A is a neuropeptide. Dev Gene Evol 204: $276-279$

LINGUEGLIA, E. (2007). Acid sensing ion channels in sensory perception. J Biol Chem 282: 17325-17329.

LINGUEGLIA, E., CHAMPIGNY, G., LAZDUNSKI, M. and BARBRY, P. (1995). Cloning of the amiloride-sensitive FMRFamide peptide-gated sodium channel. Nature 378: 730-733.

LOHMANN, J.U. and BOSCH, T.C. (2000). The novel peptide HEADY specifies apical fate in a simple radially symmetric metazoan. Genes Dev 14: 2771-2777.

McFARLANE, I.D., GRAFF, D. and GRIMMELIKHUIJZEN, C.J.P. (1987). Excitatory actions of Antho-RFamide, an anthozoan neuropeptide, on muscles and conducting systems in the sea anemone Calliactis parasitica. J Exp Biol 133: 157-168.

McFARLANE, I.D. and GRIMMELIKHUIJZEN, C.J.P. (1991). Three anthozoan neuropeptides, Antho-RFamide and Antho-RWamides I and II, modulate spontaneous tentacle contractions in sea anemones. J Exp Biol 155: 669-673.

McFARLANE, I.D., REINSCHEID, R.K. and GRIMMELIKHUIJZEN, C.J.P. 1992. Opposite actions of the anthozoan neuropeptide Antho-RNamide on antagonistic muscle groups in sea anemones. J Exp Biol 164: 295-299.

McFARLANE, I.D., HUDMAN, D., NOTHACKER, H.P. and GRIMMELIKHUIJZEN, C.J.P. (1993). The expansion behaviour of sea anemones may be coordinated by two inhibitory neuropeptides, Antho-KAamide and Antho-Rlamide. Proc Biol Sci 253: 183-188.

MILDE, S., HEMMRICH, G., ANTON-ERXLEBEN, F., KHALTURIN, K., WITTLIEB, $\mathrm{J}$, and BOSCH, T,C. (2009). Characterization of taxonomically restricted genes in a phylum-restricted cell type. Genome Biol 10: R8.
MOOSLER, A., RINEHART, K.L. and GRIMMELIKHUIJZEN, C.J.P. (1996). Isolation of four novel neuropeptides, the Hydra-RFamides I-IV, from Hydra magnipapillata. Biochem Biophys Res Commun 229: 596-602.

MOOSLER, A., RINEHART, K.L. and GRIMMELIKHUIJZEN, C.J.P. (1997). Isolation of three novel neuropeptides, the Cyanea-RFamides I-III, from Scyphomedusae. Biochem Biophys Res Commun 236: 743-749.

NOTHACKER, H.-P., RINEHART, K.L. and GRIMMELIKHUIJZEN, C.J.P. (1991a). Isolation of L-3-phenyllactyl-Phe-Lys-Ala-NH2 (Antho-KAamide), a novel neuropeptide from sea anemones. Biochem Biophys Res Commun 179: 1205-1211.

NOTHACKER, H.-P., RINEHART, K.L., MCFARLANE, I.D., and GRIMMELIKHUIJZEN, C.J.P. (1991b). Isolation of two novel neuropeptides from sea anemones: the unusual, biologically active L-3- phenyllactyl-Tyr-Arg-lle-NH2 and its des-phenyllactyl fragment Tyr-Arg-lle-NH2. Peptides (Elmsford) 12: 1165-1173.

PIEROBON, P. (2012). Coordinated modulation of cellular signaling through ligand-gated ion channels in Hydra vulgaris (Cnidaria, Hydrozoa). Int $J$ Dev Biol 56: 551-565.

PIOTROWICZ, R.S., MARTIN, J.L., DILLMAN, W.H. and LEVIN, E.G. (1997). The 27-kDa heat shock protein facilitates basic fibroblast growth factor release from endothelial cells. J Biol Chem 272: 7042-7047.

PRABHU, Y., MONDAL, S., EICHINGER, L. and NOEGEL, A.A. (2007). A GPCR involved in post aggregation events in Dictyostelium discoideum. Dev Biol 312: 29-43.

PRITCHARD, L.E. and WHITE, A. (2007). Neuropeptide processing and its impact on melanocortin pathways. Endocrinology 148: 4201-4207.

SCHALLER, H.C. and BODENMULLER, H. (1981). Isolation and amino acid sequence of a morphogenetic peptide from Hydra. Proc Natl Acad Sci USA 78: 7000-7004.

SHIMIZU, H. (2012). Transplantation analysis of developmental mechanisms in Hydra. Int J Dev Biol 56: 463-472.

SHIMIZU, H. and FUJISAWA, T. (2003). Peduncle of Hydra and the heart of higher organisms share a common ancestral origin. Genesis 36:182-186.

SRIVASTAVA, M., SIMAKOV, O., CHAPMAN, J., FAHEY, B., GAUTHIER, M.E., MITROS, T., RICHARDS, G.S., CONACO, C., DACRE, M., HELLSTEN, U. et al. (2010). The Amphimedon queenslandica genome and the evolution of animal complexity. Nature 466: 720-726.

STEELE, R.E. (2012). The Hydra genome: insights, puzzles, and opportunities for developmental biologists. Int J Dev Biol 56: 535-542.

STEELE, R. E., LIEU, P., MAI, N. H., SHENK, M. A., and SARRAS, M. P., Jr. (1996). Response to insulin and the expression pattern of a gene encoding an insulin receptor homologue suggest a role for an insulin-like molecule in regulating growth and development in Hydra. Dev Genes Evol 206: 247-259.

SUGA, H., SCHMID, V. and GEHRING, W.J. (2008). Evolution and functional diversity of jellyfish opsins. Curr Bio 18:51-55.

SUZUKI, Y., KOBAYASHI, M., MIYASHITA, H., OHTA, H., SONODA, H. and SATO, Y. (2010). Isolation of a small vasohibin-binding protein (SVBP) and its role in vasohibin secretion. J Cell Sci 123(Pt 18): 3094-3101.

TAGUCHI, A. and WHITE, M.F. (2008). Insulin-like signaling, nutrient homeostasis, and life span. Ann Rev Physiol 70: 191-212.

TAKAHASHI, T., MUNEOKA, Y., LOHMANN, J., DE HARO, L.M., SOLLEDER, G. BOSCH, T.C.G., DAVID, C.N., BODE, H.R., KOIZUMI, O., SHIMIZU, H., HATTA, M., FUJISAWA, T. and SUGIYAMA, T. (1997). Systematic isolation of peptide signal molecules regulating development in Hydra: LWamide and PW families. Proc Natl Acad Sci USA 94: 1241-1246.

TAKAHASHI, T., KOIZUMI, O., ARIURA, Y., ROMANOVITCH, A., BOSCH, T.C.G., KOBAYAKAWA, Y., MOHRI, S., BODE, H.R., YUM, S., HATTA, M. and FUJISAWA, T. (2000). A novel neuropeptide, Hym-355, positively regulates neuron differentiation in Hydra. Development 127: 997-1005.

TAKAHASHI, T., HATTA, M., YUM, S., KOIZUMI, O., KOBAYAKAWA, Y., GEE, L., OHTANI, M., FUJISAWA, T. and BODE, H.R. (2005). Hym-301, a novel peptide, regulates the number of tentacles formed in Hydra. Development 132: 2225-2234.

TAKAHASHI, T., KOIZUMI, O., HAYAKAWA, E., MINOBE, S., SUETSUGU, R., KOBAYAKAWA, Y., BOSCH, T.C,, DAVID, C.N, and FUJISAWA, T. (2009). Further characterization of the PW peptide family that inhibits neuron differentiation in Hydra. Dev Genes Evol 219: 119-129.

WEST, D.L. (1978). The epitheliomuscular cell of Hydra: its fine structure, threedimensional architecture and relation to morphogenesis. Tissue Cell 10: 629-646. WESTFALL, J.A. and GRIMMELIKHUIJZEN, C.J.P. (1993). Antho-RFamide im- 
munoreactivityin neuronal synaptic and nonsynaptic vesicles of sea anemones. Biol Bull 185: 109-114.

WESTFALL, J.A., SAYYAR, K.L., ELLIOTT, C.F. and GRIMMELIKHUIJZEN, C.J.P. (1995). Ultrastructural localization of Antho-RWamides I and II at neuromuscular synapses in the gastrodermis and oral sphincter muscle of the sea anemone Calliactis parasitica. Biol Bull 189: 280-287.
WOOD, R.L. (1979). The fine structure of the hypostome and mouth of Hydra. II. Transmission electron microscopy. Cell Tissue Res 199: 319-338.

YUM, S., TAKAHASHI, T., KOIZUMI, O., ARIURA, Y., KOBAYAKAWA, Y., MOHRI, S., and FUJISAWA, T. (1998). Anovel neuropeptide, Hym-176, induces contraction of the ectodermal muscle in Hydra. Biochem Biophys Res Commun 248: 584-590. 


\section{Further Related Reading, published previously in the Int. J. Dev. Biol.}

An organizing region in metamorphosing hydrozoan planula larvae - stimulation of axis formation in both larval and in adult tissue Melanie Stumpf, Britta Will, Karola Wittig, Jennifer Kasper, Benjamin Fischer, Jürgen Schmich, Stefanie Seipp and Thomas Leitz Int. J. Dev. Biol. (2010) 54: 795-802

Sperm-activating peptides in the regulation of ion fluxes, signal transduction and motility Alberto Darszon, Adán Guerrero, Blanca E. Galindo, Takuya Nishigaki and Christopher D. Wood Int. J. Dev. Biol. (2008) 52: 595-606

The role of alpha-amidated neuropeptides in hydroid development--LWamides and metamorphosis in Hydractinia echinata

Günter Plickert, Eva Schetter, Nicole Verhey-Van-Wijk, Jörg Schlossherr, Marlis Steinbüchel and Martin Gajewski

Int. J. Dev. Biol. (2003) 47: 439-450

Distribution and possible function of an adrenomedullin-like peptide in the developing chick limb bud

M Reza Seghatoleslami, Alfredo Martínez, Frank Cuttitta and Robert A Kosher

Int. J. Dev. Biol. (2002) 46: 957-961

Snail is an immediate early target gene of parathyroid hormone related peptide signaling in parietal endoderm formation

J M Veltmaat, C C Orelio, D Ward-Van Oostwaard, M A Van Rooijen, C L Mummery and L H Defize Int. J. Dev. Biol. (2000) 44: 297-307

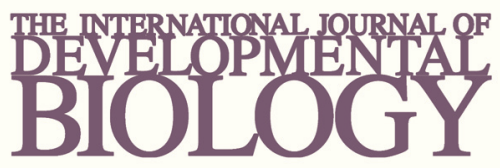

Volume 54 Nos. 6/7
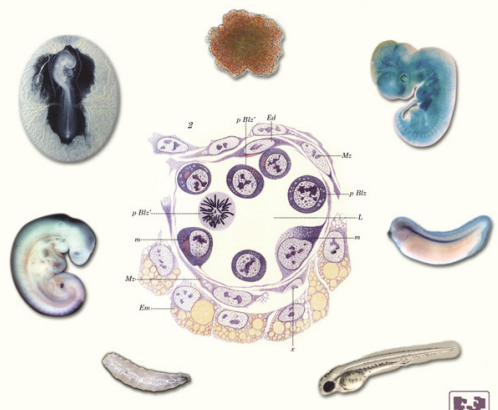

Developmental Hematopoiesis
5 yr ISI Impact Factor $(2010)=2.961$

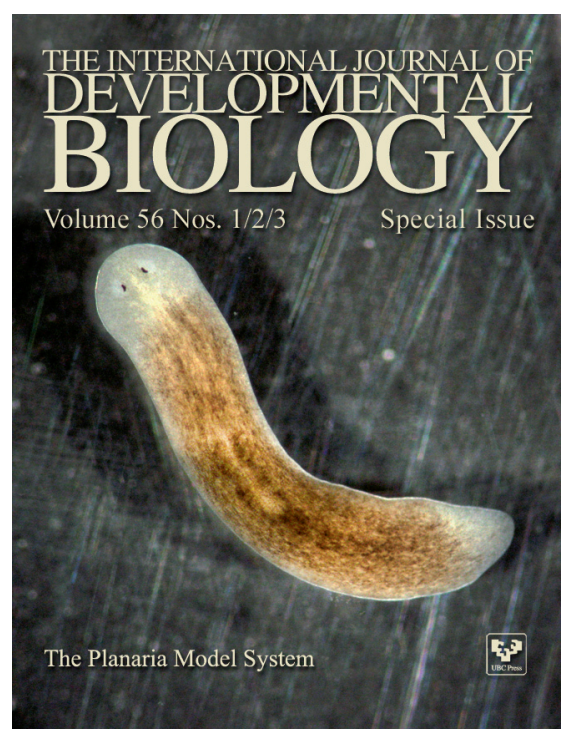

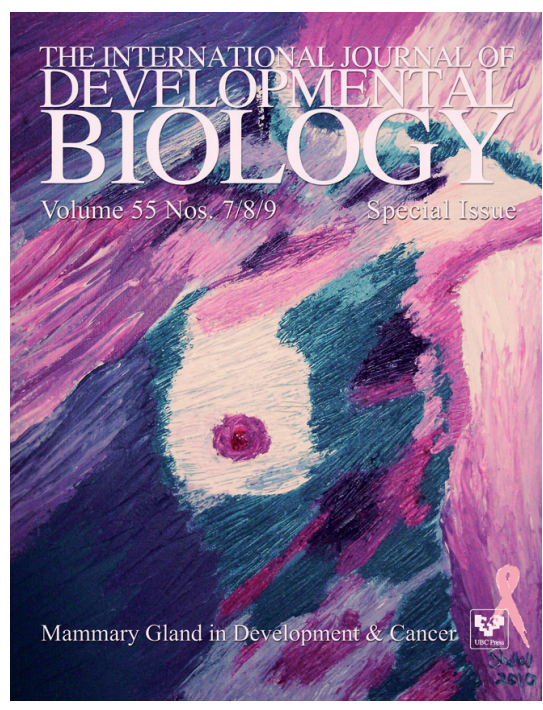

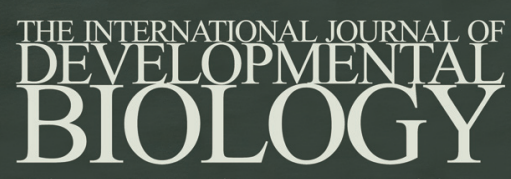

Volume 55 Nos. $4 / 5$

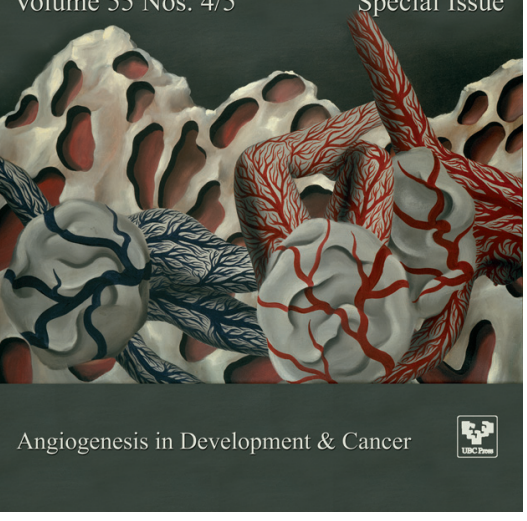

